UDC 577.25

doi: http://dx.doi.org/10.15407/ubj87.06.064

\title{
THE EFFECT OF NITRIC OXIDE ON SYNAPTIC VESICLE PROTON GRADIENT AND MITOCHONDRIAL POTENTIAL OF BRAIN NERVE TERMINALS
}

\author{
A. S. TARASENKO \\ Palladin Institute of Biochemistry, National Academy of Sciences of Ukraine, Kyiv; \\ e-mail:tas@biochem.kiev.ua
}

The effect of nitric oxide on synaptic vesicle proton gradient and membrane potential of rat brain nerve terminals was studied. It has been shown that nitric oxide in the form of S-nitrosothiols at nanomolar concentrations had no effect on the studied parameters, but caused a rapid dissipation of synaptic vesicle proton gradient and depolarization of mitochondrial membrane in the presence of a SH-reducing compound such as dithiothreitol. Both processes were reversible and the rate of $\mathrm{H}^{+}$-gradient restoration depended on the redox potential of nerve terminals, namely the molar ratio of reductant/oxidant. This facts, as well as insensitivity of the studied processes to the inhibitor of NO-sensitive guanylate cyclase such as ODQ, allow suggesting that post-translational modification of thiol residues of the mitochondrial and synaptic vesicle proteins underlies the effect of nitric oxide on the key functional parameters of presynaptic nerve terminals.

Key words: nitric oxide, presynaptic nerve terminals, synaptic vesicle proton gradient, membrane potential, SH-groups.

$\mathrm{N}$ itric oxide (NO) is a unique signaling molecule that is involved in the development of many physiological and pathophysiological processes in the body. In the central nervous system, NO participates in the formation of long-lasting and short-lasting links between neurons that underlie the cognitive functions of the brain such as memory and learning. In the CNS, NO also modulates hormone secretion, controls the sleep/wake cycle and regulates body temperature [1, 2]. Nitric oxide synthesized in the postsynaptic neuron following the activation of, for example, the NMDA-type glutamate receptors can act as a retrograde messenger diffusing easily into the presynaptic terminals and modulating the release of almost all known neurotransmitters [3]. At the presynapse, nitric oxide can also act after being released from the NO-synthesizing specific neurons or NO donors, some of which are used as drugs.

The two main hypotheses for the molecular pathways of biological action of nitric oxide at the presynapse are discussed in the literature. According to one of them, NO modulates neurotransmission processes activating soluble guanylate cyclase, which triggers an intracellular signaling cascade via
c-GMP, a secondary messenger [4, 5]. This mechanism is believed to be physiological and activated at very low NO concentrations (in the range of pico- to nanomol) that are produced during operation of the constitutive isoforms of NO-synthase [6].

S-nitrosylation of thiol groups of neuronal proteins, alteration in activity of which affects neurotransmission, is another mechanism of biological action of nitric oxide at the presynapse. To date, there are different views on whether this process is physiological. Thus, some scientists consider S-nitrosylation, along with phosphorylation, is an important mechanism of post-translational modification of proteins, which, of course, is a physiological process $[7,8]$. Others believe that S-nitrosylation of proteins occurs predominantly under pathological conditions when excess NO concentrations are produced as a result of the activation of inducible NO-synthase by, e.g. anti-inflammatory cytokines [9]. The high concentration of nitric oxide is also observed upon various neurodegenerative diseases, trauma or ischemia, which is accompanied by excitotoxicity. It is worth noting that the concentrations of nitric oxide up to $1 \mu \mathrm{M}$ were formerly considered as physiologi- 
cal [10], but now this view is subject to revision [11], and NO concentrations even in the range of several tens of nanomoles are regarded as pathological [12].

The filling of synaptic vesicles with neurotransmitters, which are released in the synaptic cleft owing to potential and transmit information to the adjacent neuron or other target cells, is one of the conditions of the normal neurotransmission process. The accumulation of neurotransmitters occurs due to the operation of vesicular transporters, which use energy of the electrochemical proton gradient generated by vesicular $\mathrm{H}^{+}$-ATPase. Thus, the proton gradient of synaptic vesicles is one of the key parameters of the presynapse that reflects the functional status of the nerve cell.

Based on the aforementioned, the aim of this work was to study the effect of nanomolar NO concentrations on the synaptic vesicle proton gradient and membrane potential of nerve terminals. As a NO donor, SNAP (S-nitroso-N-acetylpenicillamine) was selected. SNAP belongs to the class of S-nitrosothiols, which are natural metabolites of nitric oxide and in the form of which NO is mostly stored and transported in cells [13].

\section{Materials and Methods}

All experiments were performed in compliance with the "Guide for the Care and Use of Experimental Animals" approved by the Committee for control of maintenance and use of experimental animals of Palladin Institute of Biochemistry of NAS of Ukraine.

Obtaining synaptosomes from the cortical and hippocampal tissues of the rat brain. White male Wistar rats weighing 150-200 g were used in the experiments. Immediately after decapitation, the hippocampus and the cerebral cortex were isolated and homogenized using a Potter glass homogenizer (a clearance of $0.2 \mathrm{~mm}$ ) in a cooled medium consisting of $0.32 \mathrm{M}$ sucrose, $0.2 \mathrm{mM}$ EDTA, $5 \mathrm{mM}$ HEPES ( $\mathrm{pH}$ 7.4). The obtained homogenates were centrifuged for $5 \mathrm{~min}$ at $2500 \mathrm{~g}$ to precipitate the cell nuclei as well as the fragments of blood vessels and relatively large fragments of neural and glial cells. The supernatants were centrifuged for $12 \mathrm{~min}$ at $12000 \mathrm{~g}$. The resulting precipitates were considered as the crude synaptosome fractions (P2).

To obtain a fraction of purified synaptosomes, the precipitate after previous centrifugation was resuspended in the isolation medium and centrifuged for $45 \mathrm{~min}$ at $70000 \mathrm{~g}$ in Ficoll density gradient (4,
$6,13 \%)$. The fraction obtained in the interphase between 6 and 13\% Ficoll was collected, diluted by isolation medium (1:4) and centrifuged for $20 \mathrm{~min}$ at $15000 \mathrm{~g}$. The precipitate, which contained mainly purified synaptosome fraction [14] was suspended in chilled oxygenated standard saline solution of the following composition (mM/l): $\mathrm{NaCl}-126 ; \mathrm{KCl}-5$; $\mathrm{MgCl}_{2}$ - 1.4; $\mathrm{NaH}_{2} \mathrm{PO}_{4}$ - 1; HEPES - 20 (pH 7.4); $\mathrm{CaCl}_{2}-1 \mathrm{mM}$; d-glucose -10 ; pyruvate -4 . The presence of pyruvate provides the maintenance of a stable level of the plasma membrane potential as well as membrane vesicle proton gradient within 6-7 hours [15]. All procedures were carried out in the cold $\left(0-4{ }^{\circ} \mathrm{C}\right)$.

Protein concentration was determined by the Larson version of the Lowry assay [16].

Isolation of synaptic vesicles. Isolated synaptic vesicles were obtained according to De Lorenzo and Freedman procedure [17]. Briefly, synaptosomes from $\mathrm{P} 2$ fraction were lysed for $60 \mathrm{~min}$ at $40^{\circ} \mathrm{C}$ by suspending the precipitate in a solution containing 1 mM EGTA, $10 \mathrm{mM}$ Tris-HCl (pH 8.1). The supernatant, obtained after lysate having been centrifuged at $20000 \mathrm{~g}$ for $30 \mathrm{~min}$, was centrifuged at $55000 \mathrm{~g}$ for $60 \mathrm{~min}$. The resulting supernatant was again centrifuged at $130000 \mathrm{~g}$ for $60 \mathrm{~min}$ and the precipitate containing synaptic vesicles was resuspended in HEPES-buffer (10 mM HEPES-Tris (pH 7.4), $120 \mathrm{mM}$ sucrose, $140 \mathrm{mM}$ K-gluconate, $4 \mathrm{mM} \mathrm{NaCl}$ and $2 \mathrm{mM} \mathrm{MgCl}_{2}$ ) to a protein concentration of $2 \mathrm{mg} / \mathrm{ml}$.

Assessment of the level of synaptic vesicles acidification in rat brain synaptosomes. Acidification of synaptic vesicles was assessed using acridine orange (AO), a $\mathrm{pH}$-sensitive fluorescent probe that is accumulated in the acidic cell compartments proportionally to the $\mathrm{pH}$ gradient $[18,19]$. As a result, $\mathrm{AO}$ fluorescence is quenched because of protonation of the dye. The measurements were conducted using the fluorescence spectrophotometer Hitachi MPF-4 (Japan) in a thermostatic cuvette $\left(37^{\circ} \mathrm{C}\right)$ with constant stirring of synaptosome suspension (final protein concentration of $0.2 \mathrm{mg} / \mathrm{ml}$ ). Kinetics of AO uptake (final concentration of $5 \mu \mathrm{M}$ ) by synaptosomes were recorded at excitation wavelength of $490 \mathrm{~nm}$ and emission wavelength of $530 \mathrm{~nm}(5 \mathrm{~nm}$ slit) for 15 min until reaching a steady-state level $\left(F_{s t}\right)$. Thereafter, the nitric oxide donor (SNAP) was added and the alterations in fluorescence intensity were registered. The obtained data were normalized relative to $\mathrm{F}_{\mathrm{st}}$, the application point of SNAP or other substances, the effects of which were studied. 
Evaluation of changes in synaptosome membrane potential. The membrane potential of isolated nerve terminals was assessed using fluorescent potential-sensitive probe rhodamine 6G (Rh 6G) [20]. Fluorescence measurements were performed under continuous stirring of synaptosome suspension (final protein concentration of $0.15 \mathrm{mg} / \mathrm{ml}$ ) in a thermostatic cuvette $\left(37^{\circ} \mathrm{C}\right)$ at an excitation wavelength of $528 \mathrm{~nm}$ and emission wavelength of $551 \mathrm{~nm}(5 \mathrm{~nm}$ slit). Kinetics of Rh $6 \mathrm{G}$ uptake (final concentration of $0.5 \mu \mathrm{M}$ ), which was accompanied by fluorescence intensity quenching, was recorded for 2-3 min until reaching a steady-state level $\left(\mathrm{F}_{\mathrm{ss}}\right)$. Thereafter, the nitric oxide donor was added to the cuvette and kinetic changes in $\mathrm{Rh} 6 \mathrm{G}$ fluorescence intensity were recorded. In the experiments with a blocker of mitochondrial respiration, the data were shown as $\mathrm{F}=\mathrm{F}_{\mathrm{t}} / \mathrm{F}_{0}$, where $\mathrm{F}_{0}$ and $\mathrm{F}_{\mathrm{t}}$ are $\mathrm{Rh} 6 \mathrm{G}$ fluorescence intensities in the presence or absence of synaptosomes. $\mathrm{F}_{0}$ was calculated by extrapolating of the exponential decay function to the zero point.

Determination of the nitrite anion concentration. The concentration of NO, released from SNAP spontaneously or as a result of its interaction with DTT, was determined by colorimetric assay using the Griess reagent [21]. Sodium nitrite solution 0.01$10 \mu \mathrm{M}$ was used for calibration.

Statistical data analysis and plotting were performed using the "Microsoft Origin Pro 8.0" software. Statistical significance was evaluated using one-way ANOVA. Multiple comparisons were performed using the Bonferroni correction (significance criterion became more strict, that is 0.05 divided by $n$ (the number of the defined parameters)), and the differences/correlations were considered significant at $P<0.05 / n$ ).

Materials. In the experiments the following materials and reagents were used: S-nitroso-Nacetylpenicillamin (SNAP), S-nitrosoglutathione, dithiothreitol (DTT), 1H-(1,2,4)-oxidiazolo(4,3a)-quinoxalin-1-one (ODQ), rotenone, oligomycin, concanamycin A, pyruvate (sodium salt), Ficoll-400, d-glucose, HEPES (Sigma, USA); acridine orange, rhodamine 6G (Invitrogen, USA), sucrose (Merck, Germany) and other chemicals of domestic production of reagent grade (Reachim, Ukraine).

\section{Results and Discussion}

Since NO is a short-lived molecule, NO donors, which differ in the stability and release mechanism of nitric oxide, are usually used in experiments.
Relatively stable NO donor such as SNAP was selected as a model of endogenous S-nitrosothiols, in the form of which NO is mainly stored and transported in cells. In the presence of transition metal ions $\mathrm{Mn}^{2+}, \mathrm{Cu}^{2+}$ (trace of which is present in all buffers), SNAP undergoes a catalytic breakdown to $\mathrm{NO}$ and disulfides [22]. According to the literature, at the SNAP concentration in the range from 0.1 to $1.0 \mathrm{mM}$, the concentration of free NO ranged between 20 and $100 \mathrm{nM}$ [23].

Studying of the effect of nitric oxide on the proton gradient of synaptic vesicles was the first step in our work. $\mathrm{H}^{+}$-gradient is one of the components of the electrochemical membrane potential $\left(\Delta \mu \mathrm{H}^{+}\right)$, the energy of which is used by vesicular transporters to accumulate the neurotransmitters inside synaptic vesicles. So, $\Delta \mu \mathrm{H}^{+}$state directly affects the neurotransmitter uptake into vesicles, and as a consequence, the quantity of neurotransmitter released into extracellular environment at exocytosis.

$\mathrm{H}^{+}$-gradient is generated by vesicular $\mathrm{H}^{+}$ATPase (V-ATPase), which forms the positive charge and more acidic $(\mathrm{pH} \approx 5)$ environment inside the synaptic vesicles compared to the cytoplasm. This allows monitoring the processes ongoing inside the synaptic vesicles using $\mathrm{pH}$-sensitive fluorescent probes, such as acridine orange (AO). AO, being a lipophilic amine, freely permeate the vesicles, where it is protonated and accumulated. This process was accompanied by AO fluorescence quenching (Fig. 1, $A)$. The increase in fluorescence intensity indicated the proton release from the synaptic vesicles that could occur as a result of exocytosis or dissipation of the proton gradient. Both cases are illustrated in Fig. 1. The flash of AO fluorescence, whose amplitude is correlated to the content of synaptic vesicles released into the extracellular environment, was observed upon exocytosis in response to depolarizing factor, e.g., $30 \mathrm{mM} \mathrm{KCl} \mathrm{(Fig.} \mathrm{1,} \mathrm{A).} \mathrm{It} \mathrm{is} \mathrm{known} \mathrm{that}$ exocytosis is induced by the calcium ions uptake via potential-sensitive calcium channels. Thus, the absence of changes in the AO fluorescence intensity under $\mathrm{KCl}$ application in calcium-free medium indicated that the fluorescence flash had been a result of exocytosis. Another situation was observed at the dissipation of the proton gradient. As it can be seen in Fig. 1, B, the addition of concanamycin $\mathrm{A}$, the blocker of vesicle V-ATPase, to the synaptosomes, led to a gradual increase in the $\mathrm{AO}$ intensity due to the probe deprotonation on account of passive proton release from synaptic vesicles into the synaptosome cytoplasm. 
The addition of SNAP at concentrations of 0.1 and $0.5 \mathrm{mM}$ to the AO-loaded synaptosomes did not lead to noticeable changes in acidification of synaptic vesicles, however the reverse component of the further $\mathrm{KCl}$-induced response significantly slowed down (Fig. 2, A). The reverse component indicates the $\mathrm{AO}$ re-accumulation in the vesicles formed at endocytosis that follows exocytosis. Thus, the inhibition of the AO re-accumulation indicated that nitric oxide even at nanomolar concentrations (nM/l) affected the activity of vesicular V-ATPase, which began to transport protons into the vesicles slower.

It is known that the proton-transporting activity of V-ATPase as well as ATP hydrolysis by its catalytic $\mathrm{V}_{1}$ domain are sensitive to thiol-modifying agents such as $\mathrm{N}$-ethyl-maleimide [24]. It has been also shown that the $\mathrm{S}$-nitrosoglutathione inhibits the activity of the purified reconstituted into liposomes V-ATPase by disulfide bond formation between Cys254 and Cys-532 residues at the catalytic site of the enzyme [25]. These data, as well as the fact that dithiothreitol (DTT) as the SH-reducing agent facilitates reversibility of V-ATPase inactivation [25], allow suggesting that preliminary synaptosome incubation with DTT prevents the SNAP effect on the generation of a proton gradient. However, as it can be seen in Fig. 2, B, DTT did not only prevent the effect of SNAP, but on the contrary, in the presence
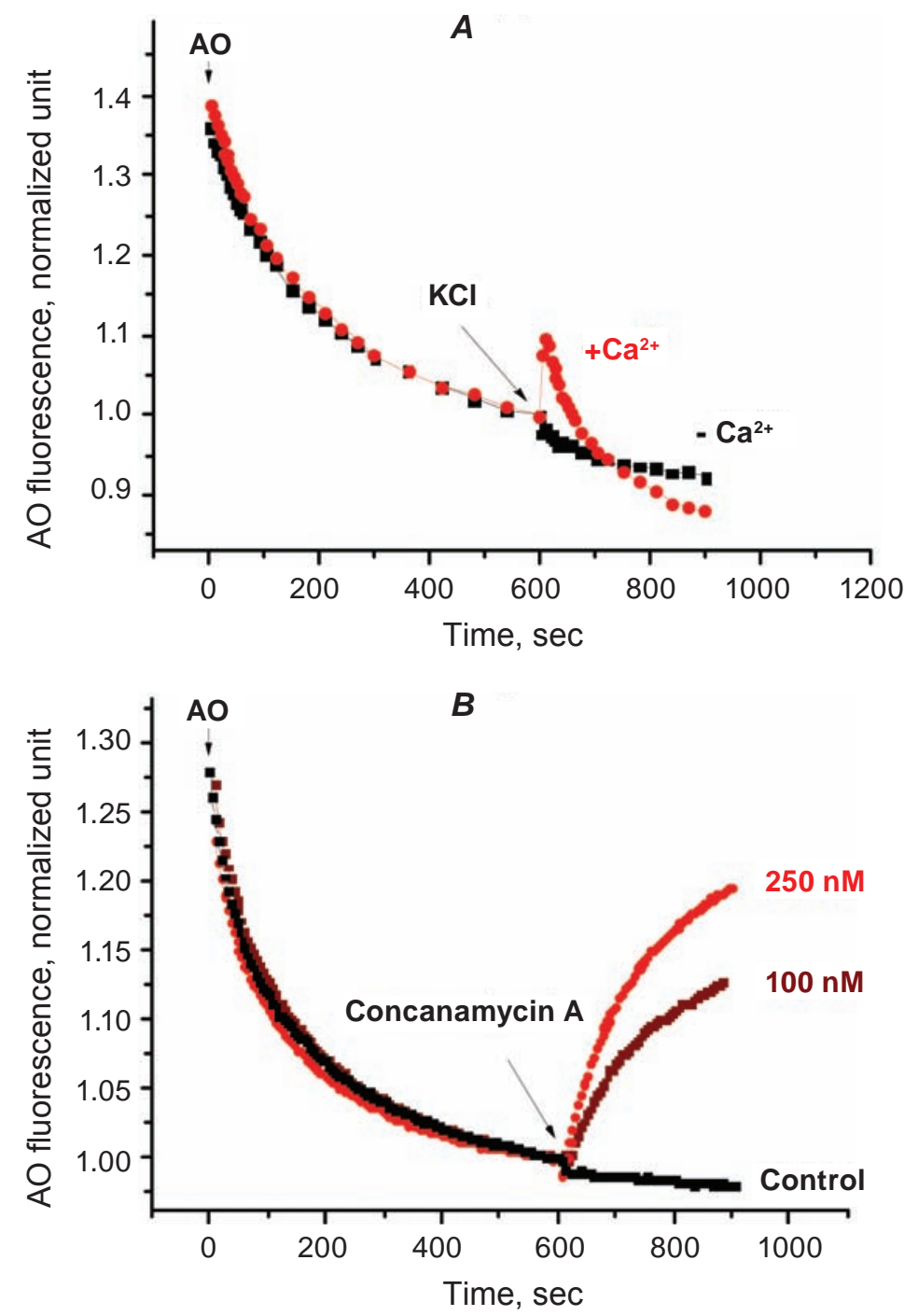

Fig. 1. Kinetics of the changes in AO fluorescence as a result of action of: $A-30 \mathrm{mM} \mathrm{KCl}$ (in a standard buffer and nominally calcium-free); $B$-various concentrations of concanamycin $A$ (100 and $250 \mathrm{~nm}$ ). Typical kinetic curves for 3-4 experiments are shown. The data are normalized relative to the point of application of $\mathrm{KCl} /$ concanamycin A 
A

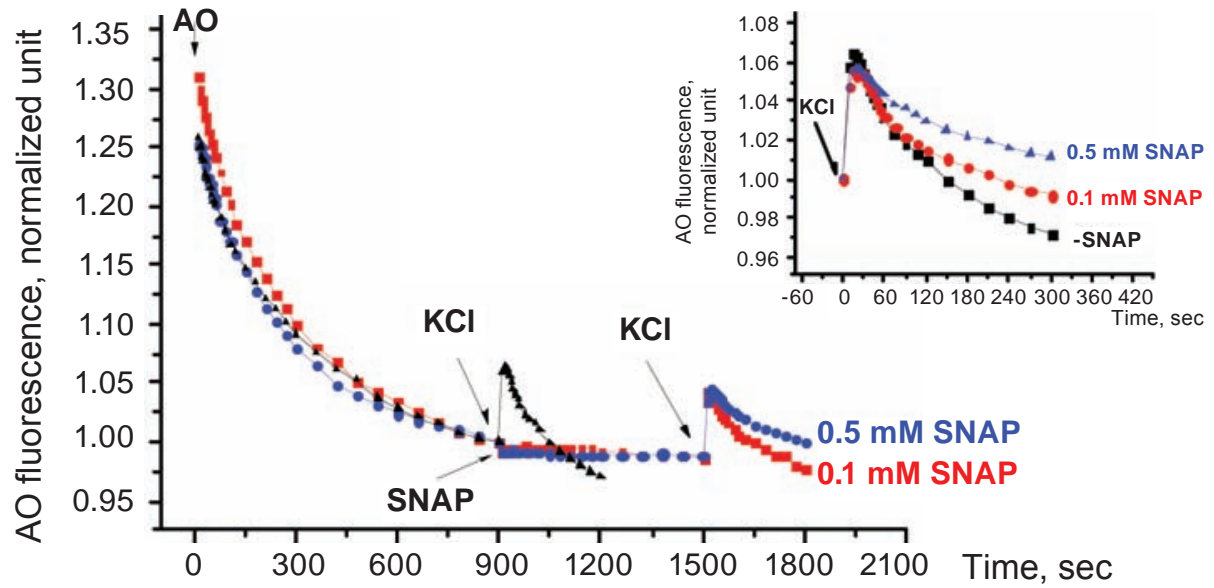

B

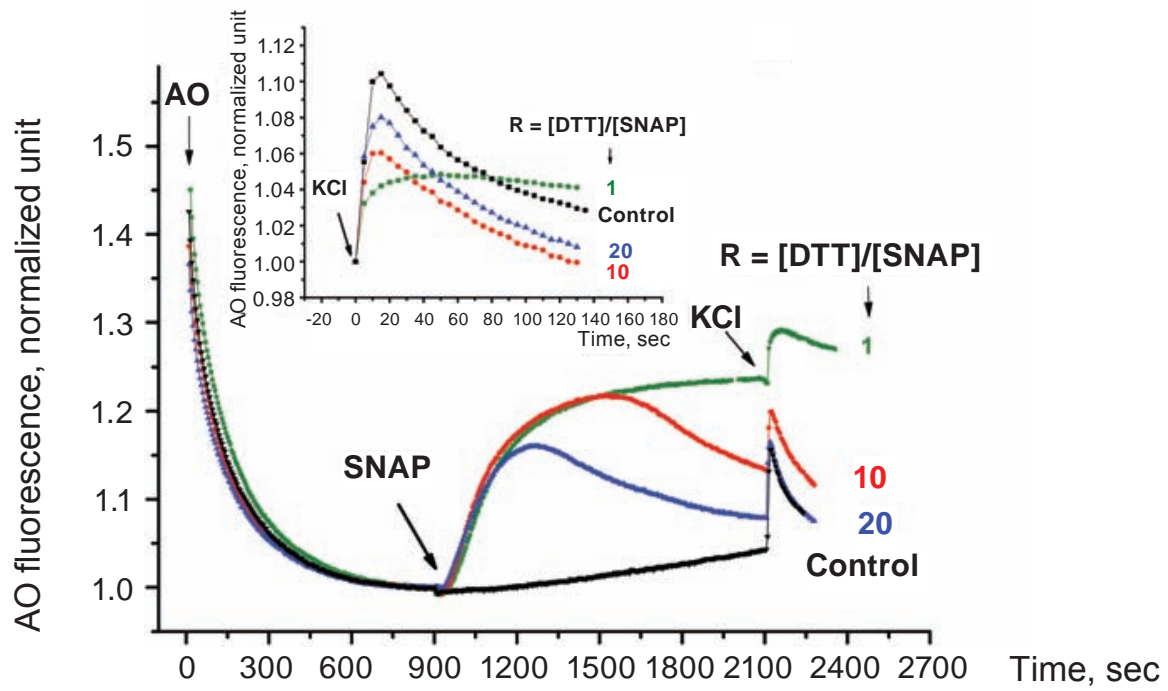

C

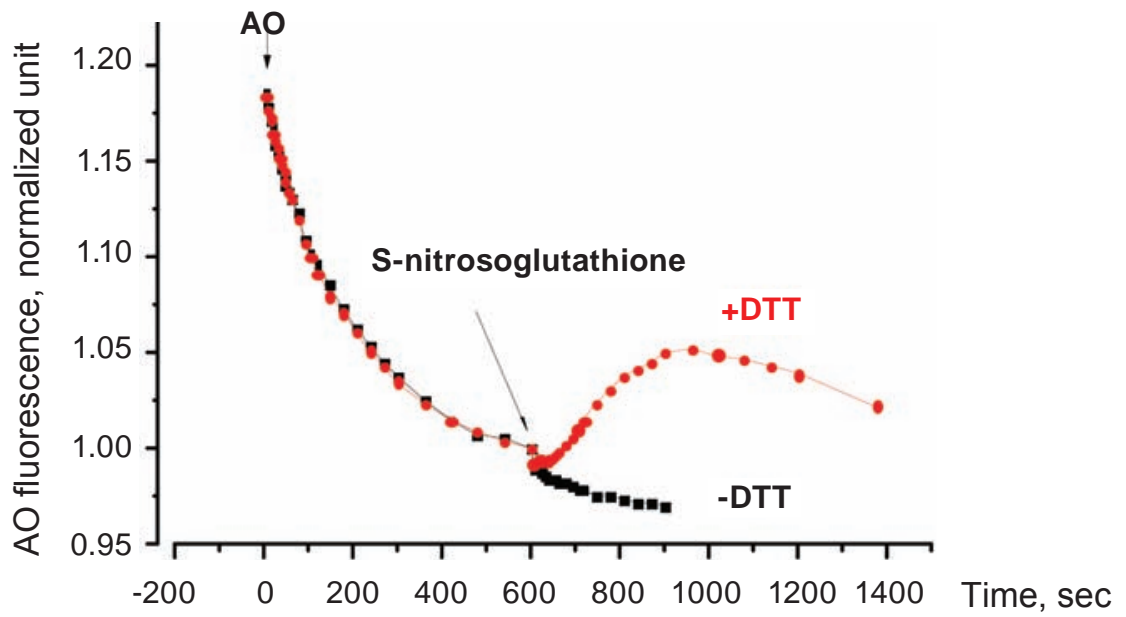

Fig. 2. Kinetics of the changes in acidification of synaptic vesicles under the action of S-nitrosothiols. A-effect of various concentrations of SNAP $(0.1$ and $0.5 \mathrm{mM})$ on vesicular $\mathrm{H}^{+}$-gradient and further synaptosome response to the introduction of $\mathrm{KCl}(30 \mathrm{mM}) ; \mathrm{B}-\mathrm{SNAP}$-induced changes in acidification of synaptic vesicles in the synaptosomes, primarily incubated with the various concentrations of DTT (0.1-2 mM). Effect of the molar ratio $R$ on the amplitude and kinetics of $\mathrm{KCl}$-induced response is shown in the inserts $A$ and $B$; $C-e f f e c t$ of $S$-nitrosoglutathione $(0.1 \mathrm{mM})$ on $\mathrm{H}^{+}$-gradient of control synaptic vesicles $(-D T T)$ and synaptic vesicles preincubated with DTT (1 mM). Typical kinetic curves for 4-5 experiments are shown. The data are normalized relative to the points of application of $\mathrm{KCl}(\mathrm{A}), \mathrm{SNAP}$ (A and B) and S-nitrosoglutathione (C) 
of DTT, a sharp increase in the AO fluorescence intensity occurred. Kinetics of this process is similar to the previously described concanamycin A induced processes suggesting that specifically dissipation of $\mathrm{H}^{+}$-gradient rather than exocytosis underlies the SNAP(+DTT) action.

Importantly, the dissipation was reversible and the rate of the reverse process was defined by the molar ratio $\mathrm{R}=[\mathrm{DTT}] /[\mathrm{SNAP}]$. At the same SNAP concentration of $0.1 \mathrm{mM}$ and DTT concentrations in the range from 0.1 to $2 \mathrm{mM}$, proton gradient was restored most fully and was faster at $2 \mathrm{mM}$ DTT, or $\mathrm{R}=20$. It should be noted that restoration of the gradient was accompanied by a restoration of fullness of synaptic vesicles ready-to-release upon the plasma membrane depolarization, as evidenced by the amplitude of fluorescence flash caused by further $\mathrm{KCl}$ addition. It is clearly seen in the insert of Fig. 2, $B$ that with the increase in $\mathrm{R}$ value, amplitude of $\mathrm{KCl}$-induced response increased, gradually approaching to the control (in the absence of SNAP) value. A similar picture was observed in the case of adding S-nitrosoglutathione (another NO donor) (Fig. 2, C) that indicates a common mechanism for S-nitrosothiols actions.

Analyzing the possible causes of the $\mathrm{H}^{+}$gradient dissipation under the SNAP action in the presence of DTT, we carried out the quantitative assessment of $\left[\mathrm{NO}^{\mathrm{x}}\right]$ released in the solution from SNAP in the absence of DTT and in the presence of SH-reducing agent. The data on the determination of the content of nitrite anion $\left(\mathrm{NO}_{2}^{-}\right)$, stable metabolite of nitric oxide, are shown in Fig. 3. As it is seen, DTT facilitates the increase in the NO amount, released from SNAP, however this increase was not significant enough to cause a substantial dissipation of the proton gradient. Therefore, it might be assumed that the effect of DTT was caused by the formation, as a result of S-transnitrosylation reaction, of highly effective compounds, which can easily oxidize SH-groups of active enzymes, in particular, ATPase, rather than the increase in the free nitric oxide concentration. Previously, the hypothesis for the formation of "unknown active compounds" has been suggested by Japanese scientists [26]. They have found that sodium nitroprusside, the NO donor, in the presence of DTT stimulated the release of noradrenaline from hippocampal slices of rat brain. This group of researchers has also shown that different NO donors, including SNAP, stimulated the neurotransmitter release in the presence of other thiols, particularly L-cysteine, and this effect was $\mathrm{Ca}^{2+}$ - and cGMP-independent [27].

As it has been shown in our further experiments, the pre-incubation of synaptosomes with ODQ $(10 \mu \mathrm{M})$, a specific blocker of NO-sensitive guanylate cyclase, had also no effect on SNAP-induced process (Fig. 4), indicating that the dissipation was not mediated by involving of cyclic GMP.

Thus, these data suggest that nitric oxide as a part of S-nitrosothiols affects proton-transporting activity of V-ATPase of synaptic vesicles resulting

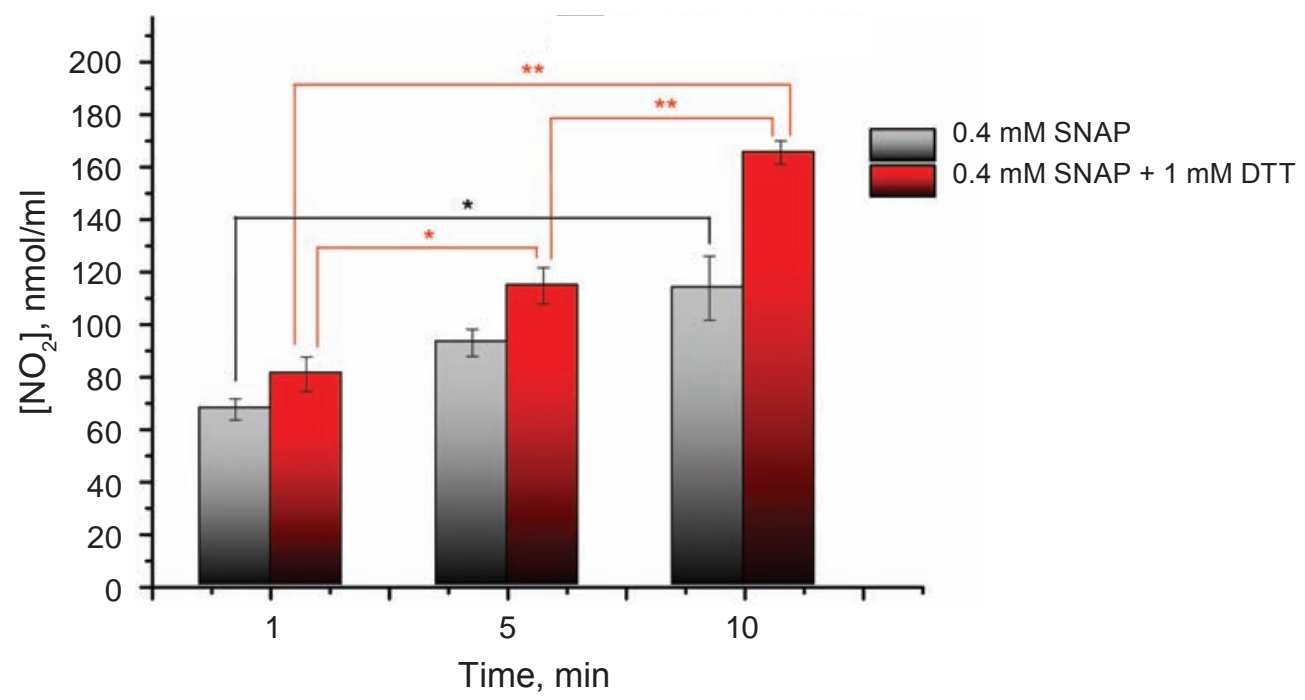

Fig. 3. The determination of the content of nitrite anion $\left(\mathrm{NO}_{2}^{-}\right)$, the stable metabolite of nitric oxide. SNAP $(0.4 \mathrm{mM})$ or SNAP $(0.4 \mathrm{mM})$ and DTT $(1 \mathrm{mM})$ were added to the standard solution, which did not contain synaptosomes; $M \pm m, n=4, * P<0.05$, ${ }^{* *} P<0.01$ 
in reduction of the vesicle acidification level. This process was reversible at nanomolar concentrations of NO, and the rate of proton re-accumulation depended on the reduction potential of the system, namely the molar ratio of reductant/oxidant.

Considering the possible causes of the decreasing of V-ATPase activity, it has been suggested that nitric oxide could affect the enzyme directly, particularly cysteine residues in its catalytic domain, or indirectly, by reducing the overall level of cytosolic ATP, required for proton transport against the gradient through V-ATPase transmembrane domain. To clarify this, a series of experiments was conducted on synaptic vesicles isolated from the synaptosomes. In this case, ATP presented in the solution with excess, that excluded the possibility of its shortage. As it can be seen in Fig. 5, concanamycin A (250 nM), added to a suspension of synaptic vesicles, induced the $\mathrm{H}^{+}$-gradient dissipation, similar to that, at its addition to synaptosomes (Fig. 1, B). However, unlike concanamycin A, SNAP application $(0.3 \mathrm{mM})$ to synaptic vesicles preincubated with DTT $(1 \mathrm{mM})$ had almost no effect on the vesicle acidification. Thus, the potent proton gradient dissipation observed upon the SNAP addition to synaptosomes (Fig. 2, B) might be caused by the decrease in the level of cytosolic ATP rather than the influence of NO on V-ATPase itself. Since the mitochondrial membrane potential is considered a driving force for ATP synthesis, the effect of SNAP on the synapto- some plasma $\left(\Delta \psi_{\mathrm{p}}\right)$ and mitochondrial $\left(\Delta \psi_{\mathrm{m}}\right)$ potentials was studied in our next experiments.

The potential-sensitive fluorescent probe Rhodamine 6G (Rh 6G), being lipophilic, easily penetrates across the plasma and mitochondrial membranes and is distributed among them according to their potential. As it was seen in Fig. 6, A, the addition of Rh 6G to synaptosomes was accompanied by probe fluorescence quenching due to its binding to the membranes, and the following application of SNAP $(50 \mu \mathrm{M})$ in the absence of DTT did not cause any changes in the Rh $6 \mathrm{G}$ fluorescence. DTT at concentration range of $0.1-2.5 \mathrm{mM}$ also had no effect on the membrane potential of synaptosomes, however, further SNAP application resulted in a dramatic increase in probe fluorescence, that indicated a substantial synaptosome membrane depolarization. Similar to the $\mathrm{H}^{+}$-gradient dissipation in synaptic vesicles, the depolarization was reversible and the rate of the reverse process was defined by molar ratio $\mathrm{R}=[\mathrm{DTT}] /[\mathrm{SNAP}]$.

To find out, how exactly plasma or/and mitochondrial synaptosome membranes in the presence of SNAP(+DTT) were depolarized, rotenone $(4 \mu \mathrm{M})$ and oligomycin $(4 \mu \mathrm{g} / \mathrm{ml})$ as blockers of complex I of respiratory chain and mitochondrial ATP synthase, respectively, were used. The simultaneous presence of the blockers in the buffer caused a complete collapse of $\Delta \psi_{\mathrm{m}}$ and had a minimal effect on $\Delta \psi_{\mathrm{p}}$ [28], which was manifested in significantly less Rh $6 \mathrm{G}$

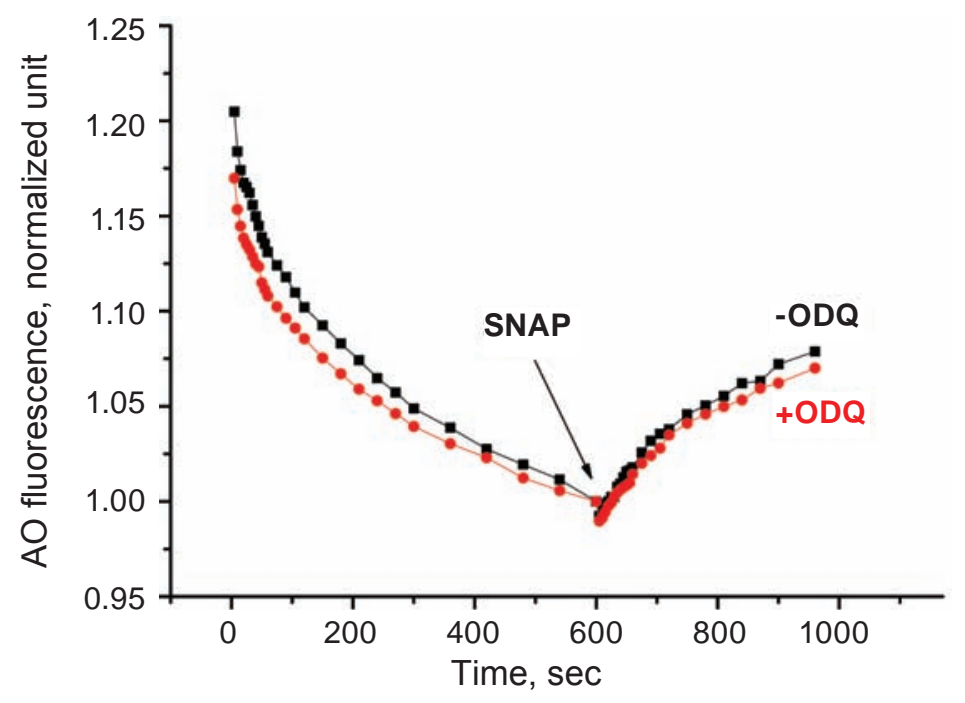

Fig. 4. SNAP(+DTT)-induced changes in acidification of synaptic vesicles in the presence of ODQ, a blocker of soluble NO-sensitive guanilate cyclase, in the incubation medium. Concentrations of SNAP was $0.5 \mathrm{mM}$, of DTT was $1 \mathrm{mM}$, and of ODQ was $10 \mu \mathrm{M}$. Typical kinetic curves for 3-4 experiments are shown. The data are normalized with respect to point of SNAP application 


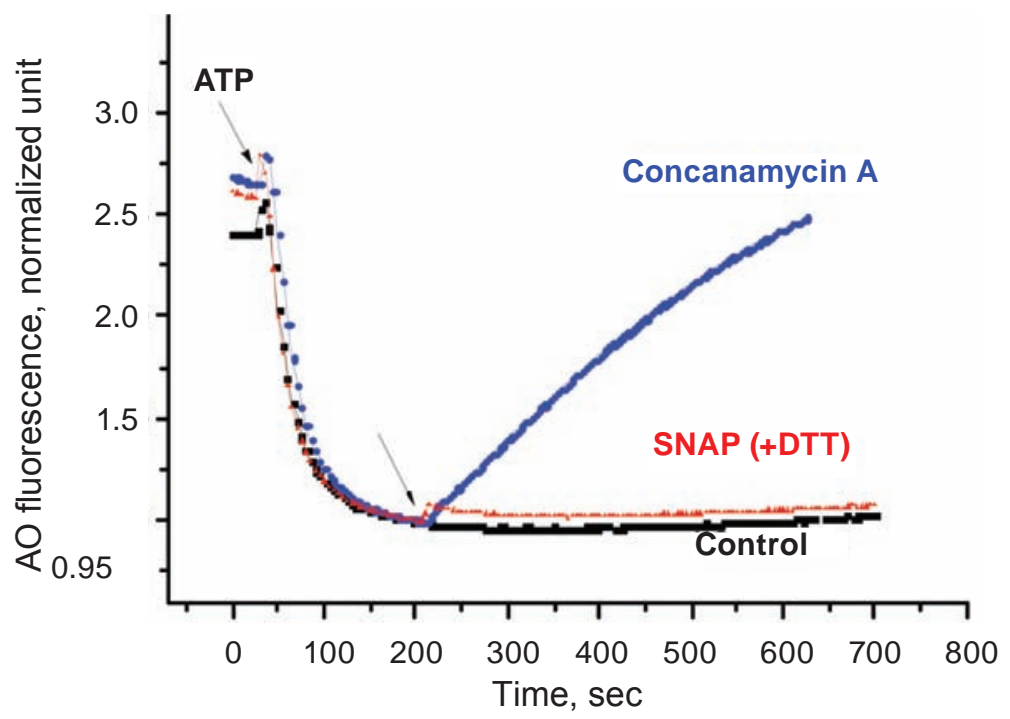

Fig. 5. The effect of SNAP and concanamycin A on acidification of synaptic vesicles, isolated from synaptosomes. SNAP and concanamycin A concentrations were $0.3 \mathrm{mM}$ and $250 \mathrm{nM}$, respectively. In the experiments with SNAP, DTT was added to incubation medium at concentration $1 \mathrm{mM}$. Addition of ATP $(0.5 \mathrm{mM})$ on the $30^{\text {th }}$ sec of registration was a trigger of AO uptake $(2 \mu M)$ into synaptic vesicles. Typical kinetic curves for 3-4 experiments are shown. The data are normalized with respect to point of SNAP / comcanamycin A application

uptake into synaptosomes owing to its binding only with the plasma membrane (Fig. 6, B). Under these conditions, consecutive additions of SNAP $(0.1 \mathrm{mM})$ and DTT $(1 \mathrm{mM})$ did not cause any changes in Rh $6 \mathrm{G}$ fluorescence, in contrast to normal conditions under which, a significant increase in fluorescence intensity was observed. These data indicate that nitric oxide as part of S-nitrosothiols at nanomolar concentrations caused depolarization of specifically the mitochondrial membrane and did not affect the plasma membrane. This is supported by the fact that the plasma membrane depolarization caused by the further addition of $\mathrm{KCl}(30 \mathrm{mM})$ was accompanied by the same change in $\mathrm{Rh} 6 \mathrm{G}$ fluorescence, regardless of the presence in the buffer of rotenone and oligomycin (Fig. 6, B).

Depolarization of the mitochondrial membrane in the cortical and hippocampal neurons by nitric oxide has been previously shown in the literature [29, 30]. According to Almeida et al. [31], NO-induced changes in mitochondrial potential are associated with the depletion of cytosolic ATP level as a result of the inhibition of mitochondrial respiration by nitric oxide. Respiratory complex IV cytochrome c oxidase, for binding sites of which nitric oxide competes with oxygen, is the most sensitive target of NO in mitochondria. Some scientists believe the inhibition of this enzyme is a manifestation of the pathological action of nitric oxide, since the inhibition occurs at NO concentrations more than a few tens of nanomole (nM/l), which are detected in vivo upon activation of the inducible form of NOsynthase [12]. However, other scientists, noting the reversibility of the inactivation of cytochrome c oxidase by low (nanomolar) concentrations of nitric oxide, considered NO as a physiological regulator of mitochondrial respiration [32, 33].

Previously, Erecinska et al. [34], studying the effect of NO-generating compounds on the energy status of neurons, have found a significant drop $(\approx 33 \%)$ in the $[\mathrm{ATP}] /[\mathrm{ADP}]$ ratio at 5 min incubation of forebrain and midbrain synaptosomes with S-nitrosocysteine $100 \mu \mathrm{M}$. Importantly, in the presence of a reduced form of glutathione $(500 \mu \mathrm{M})$, this fall was almost $67 \%$, but then the synaptosomal energy level gradually restored, and after $15 \mathrm{~min}$ of incubation the decrease in [ATP]/[ADP] ratio was already $33 \%$ (with respect to control). Thus significant changes in the [ATP]/[ADP] level in neurons under the influence of S-nitrosocysteine and glutathione found by Erecinska et al. completely correlate in time values with our data on SNAP(+DTT)induced depolarization of mitochondrial membranes (Fig. 6, A), namely: the decrease in $\Delta \psi \mathrm{m}$ (at $5^{\text {th }} \mathrm{min}$ ) coincides with the pronounced decrease in ATP, and further restoration of potential (at $15^{\text {th }} \mathrm{min}$ ) 

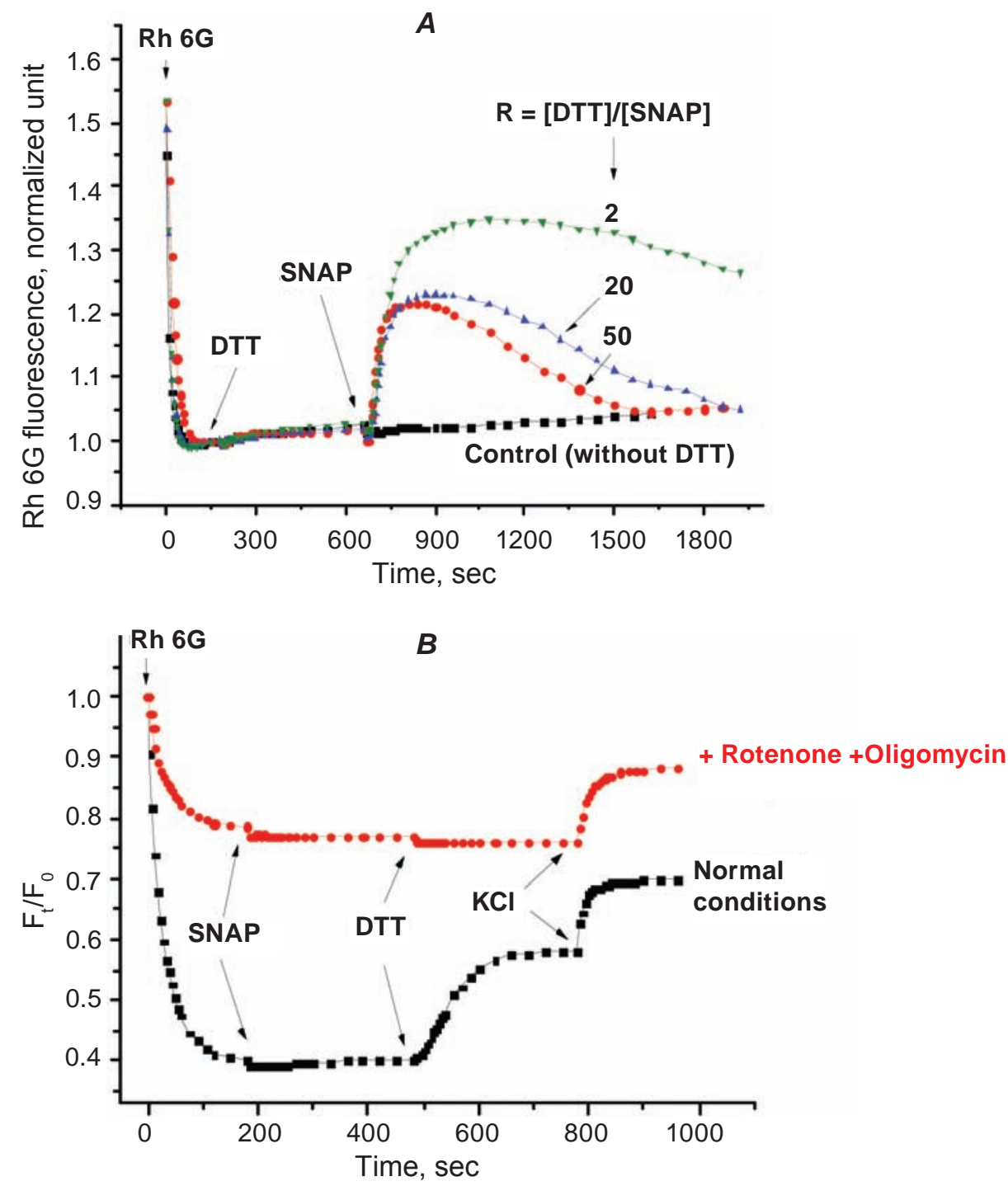

Fig. 6. Effect of SNAP and DDT on the synaptosomal membrane potential. A-kinetics of SNAP-induced changes in the synaptosomal membrane potential at different molar ratio DTT/SNAP. DTT at various concentrations (0.1, 1 and $2.5 \mathrm{mM})$ and then SNAP $(50 \mu \mathrm{M})$ were added to synaptosomes loaded with $R \mathrm{~h} 6 \mathrm{G}$ $(0.5 \mu M)$. B - comparison of the effects of SNAP $(0.1 \mathrm{mM})$, DTT $(1 \mathrm{mM})$ and $\mathrm{KCl}(30 \mathrm{mM})$ on the synaptosomal membrane potential under normal conditions and under collapse of mitochondrial potential (pre-incubation with rotenone $(4 \mu \mathrm{M})$ and oligomycin $(4 \mu \mathrm{g} / \mathrm{ml}))$. Typical kinetic curves for $4-5$ experiments are shown

coincides with the increase in [ATP]/[ADP] level. Furthermore, the kinetics of changes in the energy status of synaptosomes, reported by these scientists, agreed with the given above (Fig. 2, B) kinetics of the SNAP(+DTT)-induced dissipation of synaptic vesicle proton gradient supporting our hypothesis of the crucial role of ATP in this process.

Thus, summarizing the obtained results, it can be stated that nitric oxide in the form of $\mathrm{S}$-nitrosothiols at the nanomolar concentrations in the presence of SH-reducing compounds cause dissipation of the synaptic vesicle proton gradient, which is, most likely, the result of depletion of the cytosolic ATP level consequent to the inhibition of mitochondrial respiration by nitric oxide. Dissipation was reversible at this NO concentration range, and the $\mathrm{H}^{+}$-gradient restoration rate was defined by the redox potential of the nerve terminals, namely the molar ratio of reductant/oxidant. It was shown for the first time that the higher redox potential of the nerve terminals, the faster their basic functional parameters, such as mitochondrial membrane potential and 
synaptic vesicle proton gradient, restored to normal values under the influence of NO.

In conclusion, it should be noted that S-nitrosylation, along with phosphorylation, as reported in the recent publications, is an important mechanism for the regulation of physiological and pathophysiological processes in the cell $[8,9,35]$. Given the high oxidation potential of nitric oxide, as well as the insensitivity of the studied processes to ODQ, the inhibitor of NO-sensitive guanylate cyclase, it can be assumed that a post-translational modification of thiol residues of mitochondrial and synaptic vesicle proteins underlies the effect of nitric oxide on key parameters of the presynaptic nerve terminal.

Acknowledgements. The author would like to thank Sivko Roman V., the researcher of the Department of Neurochemistry of Palladin Institute of Biochemistry of NAS of Ukraine for the kindly providing of the fraction of isolated synaptic vesicles.

\section{ВПЛИВ ОКСИДУ АЗОТУ НА ПРОТОННИЙ ГРАДІЕНТ СИНАПТИЧНИХ ВЕЗИКУЛ ТА МІТОХОНДРІАЛЬНИЙ ПОТЕНЦАЛ НЕРВОВИХ ТЕРМІНАЛЕЙ МОЗКУ}

\section{A. С. Тарасенко}

\author{
Інститут біохімії ім. О. В. Палладіна \\ НАН України, Київ; \\ e-mail: tas@biochem.kiev.ua
}

Досліджено вплив оксиду азоту (NO) на протонний градієнт синаптичних везикул та мембранний потенціал нервових терміналей мозку щурів. Показано, що в наномолярному діапазоні концентрацій оксид азоту у вигляді S-нітрозотіолів не впливав на досліджувані параметри, однак зумовлював швидку дисипацію протонного градієнта синаптичних везикул та деполяризацію мітохондріальної мембрани в присутності SH-відновлювальної сполуки - дитіотреїтолу. Обидва процеси були оборотні, і швидкість відновлення $\mathrm{H}^{+}$-градієнтів визначалася окисно-відновним потенціалом нервових закінчень, а саме молярним співвідношенням відновник/окисник. Цей факт, а також нечутливість досліджуваних процесів до інгібітора NO-чутливої гуанілатциклази ODQ, дозволяе припустити, що в основі дії оксиду азоту на ключові функціональні па- раметри пресинаптичної терміналі лежить посттрансляційна модифікація тіолових залишків протеїнів мітохондрій і синаптичних везикул.

К л ю ч о в і с л о в а: оксид азоту, пресинаптичні нервові терміналі, протонний градієнт синаптичних везикул, мембранний потенціал, $\mathrm{SH}$ групи.

\section{ВЛИЯНИЕ ОКСИДА АЗОТА НА ПРОТОННЫЙ ГРАДИЕНТ СИНАПТИЧЕСКИХ ВЕЗИКУЛ И МИТОХОНДРИАЛЬНЫЙ ПОТЕНЦИАЛ НЕРВНЫХ ТЕРМИНАЛЕЙ МОЗГА}

\section{A. С. Тарасенко}

\author{
Институт биохимии им. А. В. Палладина \\ НАН Украины, Киев; \\ e-mail: tas@biochem.kiev.ua
}

Исследовано влияние оксида азота (NO) на протонный градиент синаптических везикул и мембранный потенциал нервных терминалей мозга крыс. Показано, что в наномолярном диапазоне концентраций оксид азота в виде $\mathrm{S}$-нитрозотиолов не влиял на исследуемые параметры, однако вызывал быструю диссипацию протонного градиента синаптических везикул и деполяризацию митохондриальной мембраны в присутствии SH-восстанавливающего соединения - дитиотреитола. Оба процесса были обратимыми, и скорость восстановления $\mathrm{H}^{+}$градиентов зависела от окислительно-восстановительного потенциала нервных окончаний, а именно от молярного соотношения восстановитель/окислитель. Этот факт, а также нечувствительность исследуемых процессов к ингибитору $\mathrm{NO}$-чувствительной гуанилатциклазы ODQ, позволяют предположить, что в основе действия оксида азота на ключевые функциональные параметры пресинаптической терминали лежит посттрансляционная модификация тиоловых остатков протеинов митохондрий и синаптических везикул.

К л ю че вы е с ло ва: оксид азота, пресинаптические нервные терминали, протонный градиент синаптических везикул, мембранный потенциал, SH-группы. 


\section{References}

1. Calabrese V., Mancuso C., Calvani M., Rizzarelli E., Butterfield D. A., Stella A. M. G. Nitric oxide in the central nervous system: neuroprotection versus neurotoxicity. Nat. Rev. Neurosci. 2007; 8(10):766-775.

2. Guix F. X., Uribesalgo I., Coma M., Muñoz F. J. The physiology and pathophysiology of nitric oxide in the brain. Prog. Neurobiol. 2005; 76(2): 126-52.

3. Esplugues J. V. NO as a signalling molecule in the nervous system. Br. J. Pharmacol. 2002; 135(5): 1079-1095.

4. Herring N., Paterson D. J. Nitric oxide-cGMP pathway facilitates acetylcholine release and bradycardia during vagal nerve stimulation in the guinea-pig in vitro. J. Physiol. 2001; 535(2): 507-518.

5. Prast J. H., Tran M. H., Fischer H., Philippu A. Nitric oxide-induced release of acetylcholine in the nucleus accumbens: role of cyclic GMP, glutamate, and GABA. J. Neurochem. 1998; 71(1): 266-273.

6. Hall C. N., Garthwaite J. What is the real physiological NO concentration in vivo? Nitric Oxide. 2009; 21(2): 92-103.

7. Hess D. T., Matsumoto A., Kim S. O., Marshall H. E., Stamler J. S. Protein S-nitrosylation: purview and parameters. Nat. Rev. Mol. Cell Biol. 2005; 6(2): 150-166.

8. Foster M. W., Hess D. T., Stamler J. S. Protein S-nitrosylation in health and disease: a current perspective. Trends Mol. Med. 2009; 15(9): 391404.

9. Zhang Y., Hogg N. S-Nitrosothiols: cellular formation and transport. Free Radic. Biol. Med. 2005; 38(7): 831-838.

10. Bishop A., Anderson J. E. NO signaling in the CNS: from the physiological to the pathological. Toxicology. 2005; 208(2): 193-205.

11. Bellamy T. C., Griffiths C., Garthwaite J. Differential sensitivity of guanylyl cyclase and mitochondrial respiration to nitric oxide measured using clamped concentrations. J. Biol. Chem. 2002; 277(35): 31801-31807.

12. Hall C. N., Attwell D. Assessing the physiological concentration and targets of nitric oxide in brain tissue. J. Physiol. 2008; 586(15): 3597-3615.

13. Kluge I., Gutteck-Amsler U., Zollinger M., Do K. Q. S-Nitrosoglutathione in rat cerebe- llum: identification and quantification by liquid chromatography-mass spectrometry. J. Neurochem. 1997; 69(6): 2599-2607.

14. Cotman C. W. Isolation of synaptosomal and synaptic plasma membrane fractions. Methods Enzymol. 1974;31:445-452.

15. Tarasenko A. S., Linetska M. V., Storchak L. G., Himmelreich N. H. Effectiveness of extracellular lactate/pyruvate for sustaining synaptic vesicle proton gradient generation and vesicular accumulation of GABA. J. Neurochem. 2006; 99(3): 787-796.

16. Larson E., Howlett B., Jagendorf A. Artificial reductant enhancement of the Lowry method for protein determination. Anal. Biochem. 1986; 155(2): 243-248.

17. De Lorenzo R. J., Freedman S. D. Calcium dependent neurotransmitter release and protein phosphorylation in synaptic vesicles. Biochem. Biophys. Res. Commun. 1978; 80(1): 183-192.

18. Zoccarato F., Cavallini L., Alexandre A. The $\mathrm{pH}$-sensitive dye acridine orange as a tool to monitor exo/endoexocytosis in synaptosomes. J. Neurochem. 1999; 72(2): 625-638.

19. Melnik V. I., Bikbulatova L. S., Gulyaeva N. V., Bazyan A. S. Synaptic vesicle acidification and exocytosis studied with acridine orange fluorescence in rat brain synaptosomes. Neurochem. Res. 2001; 26(5): 549-554.

20. Aiuchi T., Daimatsu T., Nakaya K., Nakamura Y. Fluorescence changes of rhodamine 6G associated with changes in membrane potential in synaptosomes. Biochim. Biophys. Acta. 1982; 685(3): 289-296.

21. Green L. C., Wagner D. A., Glogowski J., Skipper P. L., Wishnok J. S., Tannenbaum S. R. Analysis of nitrate, nitrite, and [15N]nitrate in biological fluids. Anal. Biochem. 1982; 126(1): 131-138.

22. Singh R. J., Hogg N., Joseph J., Kalyanaraman B. Mechanism of nitric oxide release from S-nitrosothiols. J. Biol. Chem. 1996; 271(31): 18596-18603.

23. Matthews J. R., Botting C. H., Panico M., Morris H. R., Hay R. T. Inhibition of NF- $\kappa B$ DNA binding by nitric oxide. Nucleic Acids Res. 1996; 24(12): 2236-2242.

24. Cidon S., Sihra T. S. Characterization of a $\mathrm{H}^{+}-$ ATPase in rat brain synaptic vesicles. Coupling to L-glutamate transport. J. Biol. Chem. 1989; 264(14): 8281-8288. 
25. Forgac M. The vacuolar $\mathrm{H}^{+}$-ATPase of clathrincoated vesicles is reversibly inhibited by S-nitrosoglutathione. J. Biol. Chem. 1999; 274(3): 1301-1305.

26. Satoh S., Murayama T., Nomura Y. Sodium nitroprusside stimulates noradrenaline release from rat hippocampal slices in the presence of dithiothreitol. Brain Res. 1996;733(2):167-174.

27. Satoh S., Kimura T., Toda M., Miyazaki H., Ono S., Narita H., Murayama T., Nomura Y. NO donors stimulate noradrenaline release from rat hippocampus in a calmodulin-dependent manner in the presence of L-cysteine. J. Cell Physiol. 1996; 169(1): 87-96.

28. Scott I. D., Nicholls D. G. Energy transduction in intact synaptosomes. Influence of plasmamembrane depolarization on the respiration and membrane potential of internal mitochondria determined in situ. Biochem. J. 1980; 186(1): 2133.

29. Brorson J. R., Schumacker P. T., Zhang He. Nitric oxide acutely inhibits neuronal energy production. J. Neurosci. 1999; 19(1): 147-158.

30. Solenski N. J., Kostecki V. K., Dovey S., Periasamy A. Nitric-oxide-induced depolarization of neuronal mitochondria: implications for neuronal cell death. Mol. Cell Neurosci. 2003; 24(4): 1151-1169.
31. Almeida A., Almeida J., Bolanos J. P., Moncada S. Different responses of astrocytes and neurons to nitric oxide: The role of glycolytically generated ATP in astrocyte protection. Proc. Natl. Acad. Sci. USA. 2001; 98(26): 15294-15299.

32. Brown G. C. Nitric oxide and mitochondrial respiration. Biochim. Biophys. Acta. 1999; 1411(2-3): 351-369.

33. Shen W., Hintze T. H., Wolin M. S. Nitric oxide. An important signaling mechanism between vascular endothelium and parenchymal cells in the regulation of oxygen consumption. Circulation. 1995; 92(12): 3505-3512.

34. Erecinska M., Nelson D., Vanderkooi J. M. Effects of NO-generating compounds on synaptosomal energy metabolism. J. Neurorhem. 1995; 65(6): 2699-2705.

35. Lipton S. A., Choi Y.-B., Pan Z. H., Lei S. Z., Chen H.-S. V., Sucher N. J., Loscalzo J., Singel D. J., Stamler J. S. A redox-based mechanism for the neuroprotective and neurodestructive effects of nitric oxide and related nitroso-compounds. Nature. 1993; 364(6438): 626-632.

Received 19.05.2015 